\title{
No evidence for XMRV association in pediatric idiopathic diseases in France
}

\author{
Eric Jeziorski ${ }^{1,2}$, Vincent Foulongne ${ }^{3}$, Catherine Ludwig ${ }^{2}$, Djamel Louhaem ${ }^{4}$, Gilles Chiocchia ${ }^{5}$, Michel Segondy ${ }^{3}$, \\ Michel Rodière ${ }^{2}$, Marc Sitbon', Valérie Courgnaud ${ }^{1 *}$
}

\begin{abstract}
Retroviruses have been linked to a variety of diseases such as neoplastic and immunodeficiency disorders and neurologic and respiratory diseases. Recently, a novel infectious human retrovirus, the xenotropic murine leukemia virus-related virus (XMRV), has been identified in cohorts of patients with either a familial type of prostate cancer or chronic fatigue syndrome. The apparent unrelatedness of these diseases raised the question of the potential involvement of XMRV in other diseases.

Here, we investigated the presence of XMRV in a selection of pediatric idiopathic infectious diseases with symptoms that are suggestive of a retroviral infection, as well as in children with respiratory diseases and in adult patients with spondyloarthritis (SpA). Using a XMRV env-nested PCR, we screened 72 DNA samples obtained from 62 children hospitalized in the Montpellier university hospital (France) for hematological, neurological or inflammatory pathologies, 80 DNA samples from nasopharyngeal aspirates from children with respiratory diseases and 19 DNA samples from SpA. None of the samples tested was positive for XMRV or MLV-like env sequences, indicating that XMRV is not involved in these pathologies.
\end{abstract}

\section{Findings}

Retroviruses have been isolated from a wide variety of animal species and have been linked to a broad range of diseases, including neoplasia, non-neoplastic hematological or inflammatory diseases, immunodeficiencies and neurodegenerative and respiratory syndromes [1-3]. However in humans, it was not until the early $1980 \mathrm{~s}$ that two pathogenic retroviruses were isolated, a deltaretrovirus, the human T cell leukemia virus (HTLV), and a lentivirus, the human immunodeficiency virus (HIV). Both HTLV and HIV appear to have resulted from cross-species transmissions from non-human African primates involving simian $\mathrm{T}$-cell leukemia viruses (STLV) and simian immunodeficiency viruses (SIV), respectively $[4,5]$. Interestingly, two new types of HTLV, HTLV-3 and 4 have recently been reported [6-8]. Crossspecies transmission of gammaretroviruses amongst vertebrates has also been established. For example, the avian spleen necrosis virus (SNV) derives from a murine

\footnotetext{
* Correspondence: valerie.courgnaud@igmm.cnrs.fr

'Institut de Génétique Moléculaire de Montpellier UMR 5535 CNRS, 1919 route de Mende, 34293 Montpellier cedex 5; Université Montpellier 2, Place Eugène Bataillon, 34095 Montpellier cedex 5; Université Montpellier 1, 5 Bd Henry IV, 34967 Montpellier cedex 2, France
}

leukemia virus (MLV) and a koala endogenous retrovirus (KoRV) have been shown to be related to the gibbon ape leukemia retrovirus [9]. In 2006, an infectious human gammaretrovirus was found in prostate tissue samples from cancer patients [10]. Phylogenetic analyses revealed that this virus was closely related to several known xenotropic mouse leukemia viruses (xeno-MLV), and thus was coined XMRV for xenotropic murine leukemia virus-related virus. XMRV displays more than 90\% sequence identity with MLV and harbors distinct amino acid substitutions and a short deletion in the gag leader region. Strikingly, these combined features lead to a putative absence of glycoGag, an alternative open reading frame of the gag gene that has been shown to play a role in MLV replication and pathogenesis [11]. The cellular receptor for XMRV has been shown to be the same as for xeno-MLV, i.e. XPR1 [12], a multipass membrane protein with unknown function [13]. XMRV was first described in patients who develop a familial form of prostate cancer associated with RNAse L deficiency [10]. However, in subsequent studies, a prevalence of $23 \%$ of XMRV infection in prostate cancer patients has been reported to be independent of the RNase L gene mutation [14]. More recently, XMRV has 
also been found, with a high prevalence, in the blood of patients with chronic fatigue syndrome (CFS), unveiling a potential broader prevalence of XMRV [15]. Most surprisingly, the prostate cancer and CFS XMRV isolates are almost identical with over $98 \%$ nucleotide sequence identity. This homology suggests that XMRV has recently arisen from a common ancestor, and that the number of replication cycles that took place during transmission and/or within one infected individual is limited.

The association of XMRV with these two pathologies remains debated in part due to the fact that several studies by European teams and a more recent one in the United States did not detect XMRV by PCR in either types of patients [16-22]. When detected, XMRV prevalence in the United States appears to be up to $40 \%$ and $67 \%$ in prostate cancer patients and CFS patients, respectively, while in Northern Europe, the prevalence is virtually zero. Furthermore, Lombardi et al., found a 4\% prevalence of XMRV in control patients from the same geographic region [15]. In view of the striking conservation of XMRV sequences, the lack of detection of $\mathrm{XMRV}$ is unlikely due to potential differences in PCR sensitivity. Therefore, differences in the worldwide distribution of XMRV may rather result from an infection that would have recently occurred in North America and that is not yet widespread in other parts of the world, or at least in Western Europe.

Retroviral pathogenesis most frequently involves hematopoietic, neurological and/or vascular symptoms through lytic, inflammatory or proliferative processes. In many human diseases of unknown etiology, retroviral involvement has recurrently been suspected. Since XMRV has been reported to be present in very different clinical entities and to a lesser extent in control samples, we wished to address the potential presence of XMRV in France, outside of CFS and prostate cancer.

While cross-species transmission is likely to take place during predatory interactions involving blood exchange, intraspecies spreading is most likely to occur through sexual exchanges or from mother-to-infant. Very few studies have been performed in pediatric samples to monitor potential retrovirus infection others than those with HIV and HTLV. In this study, we wanted to investigate XMRV as a possible etiologic agent for a selection of pediatric idiopathic diseases suggestive of retroviral infection.

Blood samples or synovial fluid cells were collected from pediatric patients less than 17 years of age admitted at the University Hospital of Montpellier (CHU Montpellier). This ongoing collection of pediatrics samples of idiopathic infectious diseases was started on September 2007, in accordance to the ethical guidelines of the French Ministry of Health (DC-20091052). All patients or their legal representatives have given their written informed consent.

Blood samples were drawn by venipuncture using standard phlebotomy procedures into $2 \mathrm{ml}$ sterile microtubes containing EDTA, and synovial fluids were obtained by needle puncture and transferred in special collection tubes. For each samples, at least 2 aliquots were prepared and stored at $-80^{\circ} \mathrm{C}$ for later use. Total DNA was isolated from whole blood or synovial fluid cells using the QIAamp blood kit (Qiagen, Courtaboeuf, France) according to the manufacturer's instructions. DNA concentrations were determined by Nanodrop ND-1000 spectrophotometer. To ensure quality of the DNA extracts, all samples were subjected to a singleround PCR reaction using GAPDH primers (Figure 1A). Bacterial exploration with direct examination and culture was performed in all synovial fluid samples with no bacterial agent found.

The present study included 72 samples obtained from 62 children who exhibited hematological, neurological or inflammatory pathologies. All pathologies selected are listed in Table 1. In addition, we screened 80 random nasopharyngeal aspirates collected from a cohort of children aged $<5$ years with respiratory diseases (including mostly bronchiolitis, $>90 \%$, pneumonia and asthma) [23].

We also screened samples from 19 adult patients with spondyloarthritis $(\mathrm{SpA})$, a chronic inflammatory disorder resembling the juvenile idiopathic arthritis, our largest cohort of pediatric patients. The SpA samples were previously tested for the presence of HTLV-related sequences using a sensitive semi-nested DNA amplification method allowing the detection of all PTLV-like sequences [24]. No HTLV-like sequences were found in SpA patients (unpublished data).

We designed primers to specifically target XMRV-like sequences. A 600-bp region of the SU env gene, spanning the receptor binding domain (RBD) was amplified with the following primers with positions indicated according to the XMRV VP35 sequence [10]: XenvS1: 5'-ATGGAAAGTCCAGCGTTCTCAAA-3' (5754 to 5776) and XenvAS1: 5'-ATGGGGACGCGGGGCCCTACATTG-3' (6443 to 6466) for the first round, while primers for the second round were XenvS2: $5^{\prime}$;AGGAGCCTCGGTACAACGTGACAG-3 (5840 to 5863), and XenvAS2: 5'-TGGCGGGTCAGAGAGAACAGGG-3' (6415 to 6437).

Specificity of the primers was verified in silico http:// www4a.biotec.or.th/cgi-bin/webPcr and confirmed experimentally by PCR amplification on random human DNA isolated from peripheral blood mononuclear cells (PBMCs). The sensitivity of our XMRV PCR was estimated with 10 -fold serial dilutions of a plasmid 


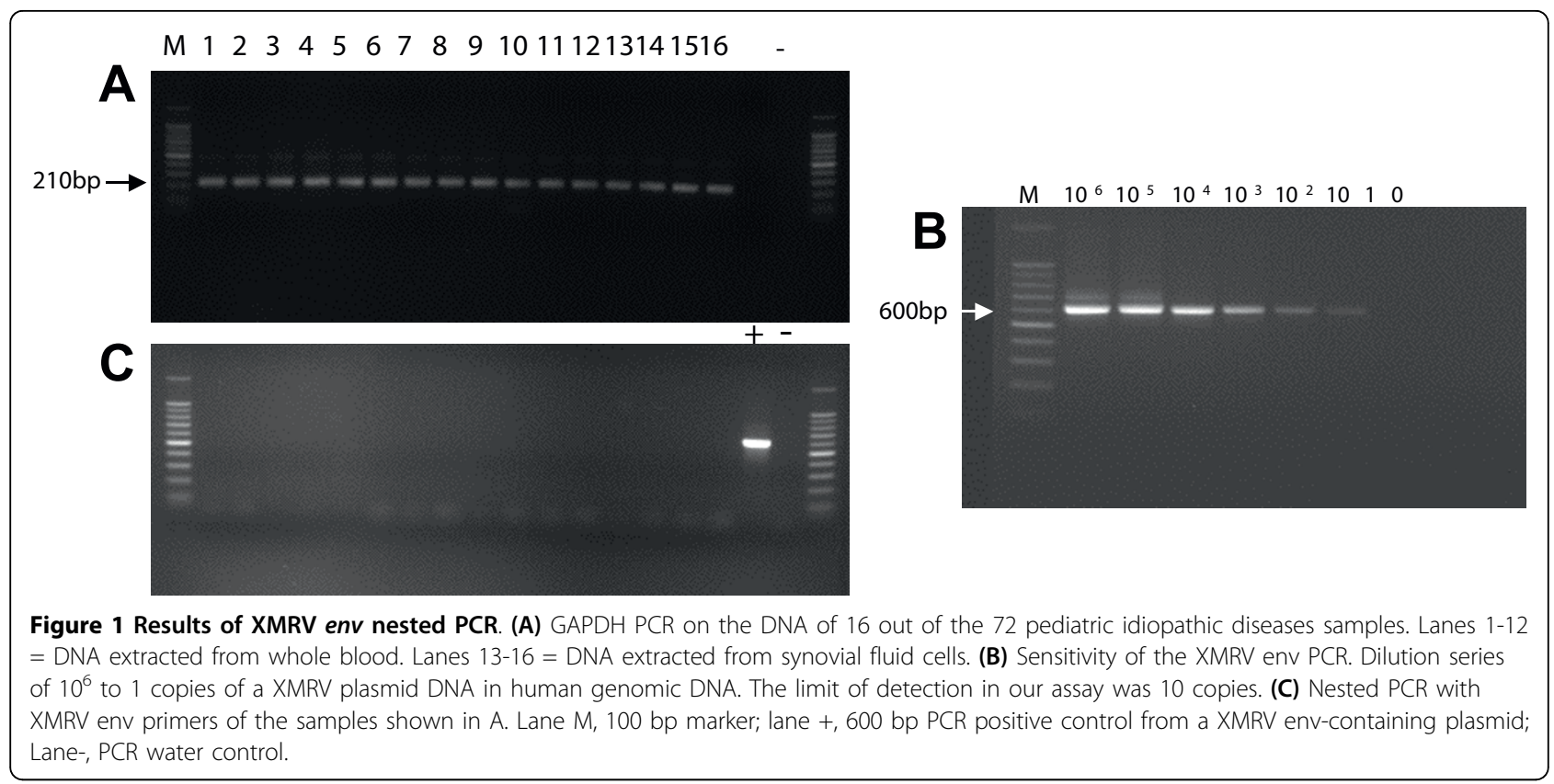

containing the env gene (kind gift from N. Fischer) in the presence of $500 \mathrm{ng}$ of human PBMC DNA. In our PCR conditions, a threshold sensitivity of 10 copies per reaction was consistently achieved (Figure 1B).

Between $300 \mathrm{ng}$ and $500 \mathrm{ng}$ of DNA for each sample were assayed by nested PCR. PCR was performed for both rounds with High Fidelity Platinum ${ }^{\circ}$ Taq DNA Polymerase (Invitrogen), including a hot start $\left(94^{\circ} \mathrm{C}\right.$ for
$2 \mathrm{~min}$ ) with the following cycle conditions: 38 cycles of denaturation at $94^{\circ} \mathrm{C}$ for $20 \mathrm{~s}$, annealing at $54^{\circ} \mathrm{C}$ for $30 \mathrm{~s}$, and extension at $72^{\circ} \mathrm{C}$ for 1 min with a final elongation step at $72^{\circ} \mathrm{C}$ for $10 \mathrm{~min}$ before cooling to $4^{\circ} \mathrm{C}$.

None of the 152 pediatric samples (72 various idiopathic diseases and 80 respiratory diseases) and the 19 SpA samples tested was positive for XMRV (Figure 1C) or related env sequence, since our primers also allowed

\section{Table 1 List of samples from pediatric patients}

\begin{tabular}{|c|c|c|c|c|}
\hline \multirow{2}{*}{$\begin{array}{c}\text { Pediatric Pathology } \\
\text { Idiopathic thrombocytopenic purpura }\end{array}$} & \multirow{2}{*}{$\frac{\text { Age range* }^{*}}{11 \mathrm{~m}-16 \mathrm{y}}$} & \multicolumn{2}{|c|}{ Number of patients } & \multirow{2}{*}{$\begin{array}{c}\text { Sample origin } \\
\text { Whole blood }\end{array}$} \\
\hline & & 9 & 7 & \\
\hline & & & 1 & Bone marrow \\
\hline & & & 1 & Whole blood - Bone marrow \\
\hline \multirow[t]{2}{*}{ Autoimmune hemolytic anemia } & $4 y-16 y$ & 3 & 2 & Whole blood \\
\hline & & & 1 & Whole blood - Bone marrow \\
\hline \multirow[t]{3}{*}{ Aregenerative anemia } & $1.5 y-8 y$ & 3 & 1 & Whole blood \\
\hline & & & 1 & Bone marrow \\
\hline & & & 1 & serum \\
\hline Idiopathic aplasia & $12 y$ & 1 & & Whole blood \\
\hline \multirow[t]{2}{*}{ Neutropenia } & $1 m-3 y$ & 4 & 3 & Whole blood \\
\hline & & & 1 & Bone marrow \\
\hline \multirow[t]{3}{*}{ Juvenile idiopathic arthritis } & $2 y-16 y$ & 34 & 5 & Whole blood \\
\hline & & & 21 & Synovial fluid cells \\
\hline & & & 8 & Whole blood - Synovial fluid cells \\
\hline Henoch-Schönlein syndrome & $6 y-6 y$ & 2 & & Whole blood \\
\hline Encephalitis & $3 y-9 y$ & 3 & & Whole blood \\
\hline Dermatomyositis & $9 y$ & 1 & & Whole blood \\
\hline Leucosis & $1.5 y-15 y$ & 2 & & Whole blood \\
\hline
\end{tabular}


us to detect both xeno-MLV and polytropic MLV $[25,26]$.

In contrast with our results on pediatrics respiratory disease samples (bronchiolitis and others), Fischer et al. found a significant proportion of XMRV gag sequences in all of their respiratory disease patient and donor groups (between 2 to 10\%). They found the highest incidence of gag XMRV detection in the group of immunosuppressed patients (adults conditioned before transplant) [27]. Although, this confirms that XMRV is more likely to emerge in the context of altered immune response, it remains perplexing that no other report found XMRV in Europe.

We showed that our nested PCR procedure is sensitive enough to detect as few as 10 copies of an XMRV env gene in a sample. Moreover, we have shown that we were able to detect XMRV-related env sequences such as xeno-MLV and the related polytropic MLV. However, we cannot formally exclude that variant viruses lacking the env sequences that match our primers would be present in some of these samples. Nevertheless, the remarkable conservation of XMRV env sequences described in all the studies published so far rather argues in favor of a bona fide absence of XMRV infection in these pathologies. Furthermore, a representative third of our samples was also unsucessfully amplified with XMRV gag specific primers (not shown).

As mentioned above, gammaretroviruses also participate in zoonotic transmissions [28]. Therefore, the absence of XMRV in pediatric patients as described here should not discourage the search for other gammaretroviruses potentially able to cross the species barrier through recognition of human receptors by their envelope glycoproteins.

\section{Abbreviations}

ENV: envelope glycoprotein; GAPDH: Glyceraldehyde 3-phosphate dehydrogenase; PCR: Polymerase Chain Reaction; PTLV: Primate T-cell lymphotropic virus; SU: Env extracellular surface component.

\section{Acknowledgements}

We thank all the members of our laboratories for their input throughout the course of this study. This work was supported in part by grants from the Association pour la Recherche sur le Cancer, The Fondation pour la Recherche Médicale and the Fondation de France (to M.Si.). M.Si. is supported by the French Institut National de la Santé et de la Recherche Médicale.

\section{Author details}

'Institut de Génétique Moléculaire de Montpellier UMR 5535 CNRS, 1919 route de Mende, 34293 Montpellier cedex 5; Université Montpellier 2, Place Eugène Bataillon, 34095 Montpellier cedex 5; Université Montpellier 1, 5 Bd Henry IV, 34967 Montpellier cedex 2, France. ${ }^{2}$ Centre Hospitalier Régional Universitaire de Montpellier, Hôpital Arnaud de Villeneuve, Service de Pédiatrie III, 371, avenue du Doyen Gaston Giraud, 34295 Montpellier cedex 5, France. ${ }^{3}$ Centre Hospitalier Régional Universitaire de Montpellier, Hôpital Saint Eloi, Laboratoire de virologie, 80 avenue A. Fliche, 34295 Montpellier cedex 5, France. ${ }^{4}$ Centre Hospitalier Régional Universitaire de Montpellier, Hôpital Lapeyronie, Service de chirurgie orthopédique infantile, 371, avenue du Doyen Gaston Giraud, 34295 Montpellier cedex 5, France. ${ }^{5}$ Institut
Cochin, INSERM U1016/CNRS UMR 8104, Université Paris Descartes Paris, France.

\section{Authors' contributions}

EJ was the principal experimentalist of this study who supervised sample collection and participated in the writing of the manuscript. VF performed the PCR experiments on the respiratory diseases samples and participated in the drafting of the article with MSe. LC, DJ and MR followed the patients and coordinated sample management. GC provided SpA DNA samples and participated in the drafting of the article. VC designed the experiments, coordinated their realization and initiated the manuscript writing. MSi and VC co-coordinated the realization of the study and co-wrote the manuscript. All authors read and approved the final manuscript.

\section{Competing interests}

The authors declare that they have no competing interests.

Received: 21 May 2010 Accepted: 2 August 2010

Published: 2 August 2010

\section{References}

1. Coffin J, Hughes SH, Varmus HE: Retroviruses Cold Spring Harbor Laboratory Press Cold Spring Harbor, NY 1997.

2. Voisset C, Weiss RA, Griffiths DJ: Human RNA "rumor" viruses: the search for novel human retroviruses in chronic disease. Microbiol Mol Biol Rev 2008, 72:157-196.

3. Palmarini M, Fan H: Retrovirus-induced ovine pulmonary adenocarcinoma, an animal model for lung cancer. J Natl Cancer Inst 2001, 93:1603-1614.

4. Apetrei C, Robertson DL, Marx PA: The history of SIVS and AIDS: epidemiology, phylogeny and biology of isolates from naturally SIV infected non-human primates (NHP) in Africa. Front Biosci 2004, 9:225-254.

5. Slattery JP, Franchini G, Gessain A: Genomic evolution, patterns of global dissemination, and interspecies transmission of human and simian T-cell leukemia/lymphotropic viruses. Genome Res 1999, 9:525-540.

6. Calattini S, Chevalier SA, Duprez R, Bassot S, Froment A, Mahieux R, Gessain A: Discovery of a new human T-cell lymphotropic virus (HTLV-3) in Central Africa. Retrovirology 2005, 2:30.

7. Wolfe ND, Heneine W, Carr JK, Garcia AD, Shanmugam V, Tamoufe U, Torimiro JN, Prosser AT, Lebreton M, Mpoudi-Ngole E, McCutchan FE, Birx DL, Folks TM, Burke DS, Switzer WM: Emergence of unique primate T-lymphotropic viruses among central African bushmeat hunters. Proc Natl Acad Sci USA 2005, 102:7994-7999.

8. Switzer WM, Salemi M, Qari SH, Jia H, Gray RR, Katzourakis A, Marriott SJ, Pryor KN, Wolfe ND, Burke DS, Folks TM, Heneine W: Ancient, independent evolution and distinct molecular features of the novel human Tlymphotropic virus type 4. Retrovirology 2009, 6:9.

9. Hanger JJ, Bromham LD, McKee JJ, O'Brien TM, Robinson WF: The nucleotide sequence of koala (Phascolarctos cinereus) retrovirus: a novel type $C$ endogenous virus related to Gibbon ape leukemia virus. J Virol 2000, 74:4264-4272.

10. Urisman A, Molinaro RJ, Fischer N, Plummer SJ, Casey G, Klein EA, Malathi K, Magi-Galluzzi C, Tubbs RR, Ganem D, Silverman RH, DeRisi JL: Identification of a novel Gammaretrovirus in prostate tumors of patients homozygous for R462Q RNASEL variant. PLoS Pathog 2006, 2:e25.

11. Corbin A, Prats AC, Darlix JL, Sitbon M: A nonstructural gag-encoded glycoprotein precursor is necessary for efficient spreading and pathogenesis of murine leukemia viruses. J Virol 1994, 68:3857-3867.

12. Dong B, Silverman RH, Kandel ES: A natural human retrovirus efficiently complements vectors based on murine leukemia virus. PLoS One 2008, 3: e3144.

13. Battini JL, Rasko JE, Miller AD: A human cell-surface receptor for xenotropic and polytropic murine leukemia viruses: possible role in $\mathrm{G}$ protein-coupled signal transduction. Proc Natl Acad Sci USA 1999, 96:1385-1390.

14. Schlaberg R, Choe DJ, Brown KR, Thaker HM, Singh IR: XMRV is present in malignant prostatic epithelium and is associated with prostate cancer, especially high-grade tumors. Proc Natl Acad Sci USA 2009, 106:16351-16356.

15. Lombardi VC, Ruscetti FW, Das Gupta J, Pfost MA, Hagen KS, Peterson DL, Ruscetti SK, Bagni RK, Petrow-Sadowski C, Gold B, Dean M, Silverman RH, 
Mikovits JA: Detection of an infectious retrovirus, XMRV, in blood cells of patients with chronic fatigue syndrome. Science 2009, 326:585-589.

16. D'arcy F, Foley R, Perry A, Marignol L, Lawler M, Gaffney E, Watson RGW Fitzpatrick JM, TH L: No evidence of XMRV in irish prostate cancer patients with the R462Q mutation. European Urology Supplements 2008, 7:271

17. Erlwein O, Kaye S, McClure MO, Weber J, Wills G, Collier D, Wessely S, Cleare A: Failure to detect the novel retrovirus XMRV in chronic fatigue syndrome. PloS One 2010, 5:e8519.

18. Fischer N, Hellwinkel O, Schulz C, Chun FK, Huland H, Aepfelbacher M, Schlomm T: Prevalence of human gammaretrovirus XMRV in sporadic prostate cancer. J Clin Virol 2008, 43:277-283.

19. Groom HC, Boucherit VC, Makinson K, Randal E, Baptista S, Hagan S, Gow JW, Mattes FM, Breuer J, Kerr JR, Stoye JP, Bishop KN: Absence of xenotropic murine leukaemia virus-related virus in UK patients with chronic fatigue syndrome. Retrovirology 2010, 7:10.

20. Hohn O, Krause H, Barbarotto P, Niederstadt L, Beimforde N, Denner J, Miller K, Kurth R, Bannert N: Lack of evidence for xenotropic murine leukemia virus-related virus(XMRV) in German prostate cancer patients. Retrovirology 2009, 6:92.

21. van Kuppeveld FJ, de Jong AS, Lanke KH, Verhaegh GW, Melchers WJ, Swanink CM, Bleijenberg G, Netea MG, Galama JM, van der Meer JW: Prevalence of xenotropic murine leukaemia virus-related virus in patients with chronic fatigue syndrome in the Netherlands: retrospective analysis of samples from an established cohort. Bmj 2010, 340:c1018.

22. Switzer WM, Jia H, Hohn O, Zheng HQ, Tang S, Shankar A, Bannert N, Simmons G, Hendry RM, Falkenberg VR, Reeves WC, Heneine W: Absence of evidence of Xenotropic Murine Leukemia Virus-related virus infection in persons with Chronic Fatigue Syndrome and healthy controls in the United States. Retrovirology 2010, 7:57.

23. Foulongne $V$, Olejnik $Y$, Perez V, Elaerts $S$, Rodiere $M$, Segondy M: Human bocavirus in French children. Emerg Infect Dis 2006, 12:1251-1253.

24. Kim FJ, Lavanya M, Gessain A, Gallego S, Battini JL, Sitbon M, Courgnaud V: Intrahost variations in the envelope receptor-binding domain (RBD) of HTLV-1 and STLV-1 primary isolates. Retrovirology 2006, 3:29.

25. Alamgir AS, Owens N, Lavignon M, Malik F, Evans LH: Precise identification of endogenous proviruses of NFS/N mice participating in recombination with moloney ecotropic murine leukemia virus (MuLV) to generate polytropic MuLVs. J Virol 2005, 79:4664-4671.

26. Jung YT, Wu T, Kozak CA: Characterization of recombinant nonecotropic murine leukemia viruses from the wild mouse species Mus spretus. J Virol 2003, 77:12773-12781.

27. Fischer N, Schulz C, Stieler K, Hohn O, Lange C, Drosten C: Xenotropic murine leukemia virus-related gammaretrovirus in respiratory tract. Emerg Infect Dis 2010, 16(6):1000-2.

28. Denner J: Transspecies transmissions of retroviruses: new cases. Virology 2007, 369:229-233.

doi:10.1186/1742-4690-7-63

Cite this article as: Jeziorski et al: No evidence for XMRV association in pediatric idiopathic diseases in France. Retrovirology 2010 7:63.

\section{Submit your next manuscript to BioMed Central and take full advantage of:}

- Convenient online submission

- Thorough peer review

- No space constraints or color figure charges

- Immediate publication on acceptance

- Inclusion in PubMed, CAS, Scopus and Google Scholar

- Research which is freely available for redistribution

Submit your manuscript at www.biomedcentral.com/submit
Biomed Central 